\title{
Lessons Learned from the Student's Surgery Academic League: Is It Worth It?
}

\section{Lições Aprendidas com a Liga Estudantil de Cirurgia: Vale a Pena?}

\section{KEYWORDS}

- Medical Education.

- General Surgery.

- Inguinal Hernia.

- Surgical Procedures.

- Operating Room Technicians.

\author{
Luiz Eduardo Correia Miranda ${ }^{1}$ (D) \\ Ana Clara Galindo Miranda ${ }^{1}$ (D) \\ Diego Laurentino de Lima ${ }^{\mathrm{I}}(\mathrm{D}$ \\ Ana Karla Alves Arraes ${ }^{1}$ (D)
}




\section{PALAVRAS-CHAVE}

- Educação Médica.

- Cirurgia Geral.

- Hérnia Inguinal.

- Procedimento Cirúrgico.

- Auxiliares de Cirurgia.

\section{RESUMO}

Introdução: Um dos grandes desafios dos currículos de escolas médicas é oferecer treinamento em técnicas cirúrgicas básicas que permitam ao egresso de Medicina desenvolver competências para atender a casos simples que se apresentam à assistência primária do SUS. A fim de abordar o problema da qualificação técnicocirúrgica dos estudantes de Medicina e aproveitar o apelo das ligas, foi proposto e realizado um projeto de assistência cirúrgica a pacientes portadores de hérnia inguinal, baseado em ligas acadêmicas. O objetivo do estudo é expor e discutir os resultados e a experiência acadêmica aprendida com a Liga de Cirurgia de Hérnia Inguinal. Métodos: Este é o relato da experiência de três anos com um grupo de liga acadêmica para abordar o problema da qualificação técnico-cirúrgica de estudantes de Medicina e que se aproveita do apelo das ligas acadêmicas entre estudantes de Medicina. Os participantes foram um professor de cirurgia geral, um anestesista e estudantes de graduação em Medicina interessados na clínica cirúrgica, da Faculdade de Medicina da Faculdade de Medicina da Universidade de Pernambuco, Recife, Brasil. Resultados: Vinte e quatro estudantes foram atendidos. Operaram-se 86 pacientes. Realizaram-se dois seminários com nove aulas e uma oficina de técnicas cirúrgicas. Um trabalho intitulado "Liga de cirurgia de hérnia inguinal" foi apresentado. Não se observou recorrência de hérnia; as complicações cirúrgicas foram mínimas e em pequeno número. Os estudantes mostraram rápido desenvolvimento de habilidades cirúrgicas, interpessoais e de comunicação. Entretanto, esse modelo de ensino suporta um pequeno número de estudantes e gera grande competição para os residentes de cirurgia geral em seu primeiro ano no Hospital Universitário. Conclusão: A liga de cirurgia proporciona aos estudantes uma rica experiência pedagógica, oferecendo a oportunidade de qualificação técnica e humana. No entanto, o modelo proposto apresenta limitações. De acordo com o nosso julgamento, não representa a solução para as falhas e omissões no currículo da grade universitária.

Received on 11/07/19

Accepted on 12/15/19

\section{INTRODUCTION}

The national curriculum guidelines for the graduation course in Medicine, established on June 20, $2014^{1}$ by Resolution number 3 of the Brazilian Ministry of Education, define a professional competence profile for doctors comprising humanistic, critical, reflexive and ethical skills, with generalist competence to act in the different levels of the health care systems. ${ }^{1}$ More than a technical professional, the guidelines aim at the qualification of a professional concerned with offering humanized, integral and equitable care. For the planners of the medical schools' curriculum, it is a challenge to meet all the guidelines required by the document ${ }^{2}$. One of these great challenges is to offer training in basic surgical techniques, which allows medical graduates to develop competences to take care of simple cases that are present in the primary care level of the Brazilian National Public Health System (SUS - Sistema Único de Saúde), in addition to being able of evaluating and presenting solutions to simple surgical complications that can be solved in this primary care level. To relieve the suffering of the sick person and the overload of patients in the emergence units of the large hospitals, in a country with a sociodemographic profile such as Brazil ${ }^{3}$, where there are millions of poor people receiving insufficient medical care, as well as the outdated hospital facilities, badly equipped and in need of resources must be a concern of the medical curriculum planners.

Up to the end of the last century, still based on the Flexnerian ideas, these skills were developed in anesthetized live animals, but the sacrifice of animals for this purpose became socially unacceptable $e^{4,5,6}$. The teaching of surgical basic skills started being carried out in artificial models ${ }^{7,8}$ with several problems inherent to this model: investment of assets to keep the models new and in good use conditions, the excessive number of students in the medical schools, which reduces the scarce opportunities for practice, the limitation to develop abilities and attitudes inherent to the care for a human being undergoing acute suffering ${ }^{9}$, less practical exposure to situations inducing reflection and attitudes, among others. The argument used by the directors of medical schools, that these abilities would be developed during internship, is a fallacious one. Throughout this period, the student suffers direct competitiveness from the resident doctors, who are eager for opportunities. In addition to that, the number of students in medical schools, not even counting those in school-hospitals, easily reaches the hundreds, which obviously limits the learning opportunities.

While these challenges occur, we have been observing the creation, proliferation and organization of students' groups of interest, or academic leagues ${ }^{10}$ These are associations of students, teachers and professionals with the purpose of providing medical care to a specific field or disease, in addition to teaching and research. The first Brazilian academic league (Syphilis Combat) was created in the Medical School of the University of São Paulo in $1920 .^{11}$

Despite all the well-known criticism to academic leagues ${ }^{12}$, the appeal that they exert on the students is undeniable, due to the fact that they allow the students to have early access to clinical practice.

\section{Challenge}

In order to approach the problem of the technical-surgical qualification of medical students and taking advantage of the academic leagues' appeal, LECM, a professor of general surgery, proposed and independently carried out a surgical care project to treat patients with inguinal hernia. It is constituted by the Inguinal Hernia Surgery academic league, comprising only doctors and students.

REVISTA BRASILEIRA DE EDUCAÇÃO MÉDICA

2 44 (1) : e039; 2020 
The aim of the present study is to disclose and discuss the results and the academic experience learned from the Inguinal Hernia Surgery academic league.

\section{Program Design}

Medical students who were interested in surgical clinic were invited to learn the surgeon's daily practice, without the interference of the resident doctors. The chosen model comprised the inguinal hernia surgery, as it was a simple and fast surgery type. Created as the Inguinal Hernia Surgery Academic League in 2007, it started working as from October 2007 and during the whole year of 2008, as a pilot project, comprehending six invited students who showed the human profile suitable for the task. In 2009 and 2010, the group started working as a project of Extended Education of the School of Medical Sciences, University of Pernambuco, offering a scholarship to one of the students, with the last group being created in 2010. The activities were concentrated on Friday afternoon, which it is usually a free time for students, so as not to disturb the other curriculum activities and were held in the premises of University Hospital Oswaldo Cruz, University of Pernambuco. On Fridays, from 10 to 12 oclock, the patients were seen in our ambulatories and in the afternoon, surgeries were performed. Visits to the wards and the discharges from hospital were carried out on Saturday morning.

\section{The Students}

Each group included nine students from the second year of activities, excluding the internship students. Six students were interested in surgical practices and three students in anesthesiology. The first group included students who had already performed research activities with the project proponent and therefore had his trust. The subsequent groups were selected by means of a public examination, as well as by the analysis of the academic transcript. For the examination, a seminar on the Hernia group was offered during the University Week, an annual event held by the University of Pernambuco aiming at appreciating the teaching, extended education and research. The lessons were prepared and presented by the students themselves, who showed remarkable selflessness before their colleagues; the lessons were carried out under the direct supervision of the professor and involved clinical and surgical aspects, as well as aspects inherent to SUS and to humanization. After the lectures, the professional in charge (LECM) provided the students with the criticism that led them to develop the public communication skills. In addition to the lessons, a workshop on knot tying and suturing techniques was offered. The students were divided into groups of nine, each group under the supervision of a student from the group. The manual and instrumental surgical knots and the various types of suture were demonstrated to them, providing an opportunity for training in craft models made by the students themselves.

In order to receive a new group of students, an examination with 20 tests was prepared and the students who showed the best performance were called for the analysis of the academic transcript. Students with previous annotations related to behavior issues were disqualified. Each group of students could stay in the Group for up to one year and the student could give up at any moment, without any damage to this academic performance.

The patients

The patients were selected from the General Surgery ambulatory of Oswaldo Cruz University Hospital. Only simpler cases, likely to be operated on by means of local anesthesia and in patients with no clinical complications, were selected.

All the steps of medical care, from welcoming the patients up to the admission consultation, including the anamnesis and physical exam, pre-surgery preparation, admission to hospital for surgery, post-surgery management, medical discharge and post-surgery ambulatory return were conducted by the students under the professor's direct guidance and supervision, both in presence and constant. At most two patients could be treated weekly. The students were divided in shifts in the different actions. They had, therefore, a wide opportunity of getting to know and understanding the mechanisms of functioning of a SUS hospital, both in the ambulatory and in the hospital internship, from the bureaucracy involved, its limitations and difficulties, up to the problems and practical daily issues. During the attendance, the improvement of attitudes that would value the deference to the patient, with special attention to his suffering and respect for the human being's diversity was demanded. Behaviors such as receiving the patient at the consultation room door, giving the patients the doctor's personal phone number, phoning them to get to know if the post-surgery phase went well, or if the patients would be able to buy the prescribed medication and able of dressing the surgical wounds at home were specially guided and appreciated. Behaviors such as punctuality, attendance and friendliness were considered indispensable.

\section{Development of surgical skills}

All the usual ethical requirements adopted for the SUS patients, including the free and informed term of consent, were equally adopted for the patients of the group, who were informed that the ambulatory was part of the academic project under the leadership and supervision of the surgeon in charge (LECM).

The surgery was performed under local anesthesia or spinal block, always performed by the same anesthesiologist (AKAA), who was part of the group and who guided the students during the transoperative stage on the aspects inherent to the anesthesia: used drugs and their desirable and undesirable effects, pharmacology of the drugs, transoperative monitoring, postoperative recovering, among others.

The surgery was performed by the professor in charge (LECM), exclusively with the help of the students, without the interference of the resident doctors. In all the cases, without any exception, the inguinal herniorrhaphy was carried out by open approach with mesh implant Ultrapro model, $6 \times 11 \mathrm{~cm}$ (Ethicon, Johnson \& Johnson do Brasil, Indústria e Comércio de Produtos para a Saúde Ltda). While performing the operation, the professor instructed the students in relation to the inguinal anatomy, the physiopathology of the disease, the history of the surgery and the basic surgery technique. When the students were already used to the surgery and had trained enough in cheap and simple artificial models, such as artificial foam or chicken legs, they were allowed to perform elementary surgical steps, such as the simple stitch, the skin incision, the tying of small vases or the dissection of the subcutaneous ones. The technical aspects such as washing of the hands, preparation of the surgical table, functioning of the surgical floor and materials and sterilization center were taught and trained, and the students were expected to follow them. When the surgery was over, the students were guided in relation to the postoperative care and prescription, complications and

REVISTA BRASILEIRA DE EDUCAÇÃO MÉDICA

3 44 (1) : e039; 2020 
intercurrences. Diet after 12 hours, suitable hydration, drugs to control the pain and vomits and general nursing care were prescribed. The anesthesia recovery was conducted by the doctor in charge of the hospital post-anesthesia care unit.

There were at least two postoperative medical visits, one on the seventh and the other on the thirtieth day. During this important contact with the patient, the students learned how to recognize simple surgical complications, such as seromas or hematomas, as well as to solve them. After the second return visit, if a longer follow-up was required, the patients were referred to the general surgery ambulatory, where they were followed by the surgeon in charge of the group (LECM).

\section{RESULTS}

The Inguinal Hernia surgery league worked for three years. During these years, twenty-four students were trained and ninety-six patients were operated on. In each symposium, two seminars with nine lectures and one workshop were held on knots and suturing techniques. One paper entitled "Inguinal Hernia Surgery League" was presented in the $47^{\text {th }}$ Brazilian Congress of Medical Education, held in Curitiba, in 2009.

Among the 24 attended students, $75 \%$ became anesthesiologists or surgeons. There were no dropouts. The students created a website in the Internet (https://sites.google.com/site/ligadaherniainguinal/), using a free resource from the Google sites platform. The site worked as an interface between the students and the group's members, speeding up the public examinations and disclosing the surgery schedules and the students' topics of interest.

\section{Surgical results}

The surgical results cannot be compared to the ones published by large series of inguinal hernia surgeries because we only operated on very simple cases, therefore subjected to better results. We did not observe hernia recurrences and the surgical complications were minimum and in a small number. One operatory wound infection with dehiscence of the subcutaneous layer was observed in an adolescent with a severe cognitive impairment, who, according to his mother, manipulated the operatory wound with dirty hands, which she could not control. This case was treated with antibiotics and local dressings, without the need for hospitalization, and was successfully cured in a few days.

The two held seminars and examinations attracted crowds of students. As the registration for the group was open to students from other medical schools, the demand was huge. The demand of patients for assistance by the group was also large. As the admitted patients were relatively few, the waiting time for surgeries was also short, in comparison to the patients who stay for years and years in the SUS list, waiting for an inguinal hernia correction surgery. Moreover, the humanized and personal care provided by the students was well-known. Therefore, it was not unusual that the patients spontaneously requested to be cared by the members of this group.

Although it was not the group's purpose, some students showed a fast development of surgical skills, demonstrating knowledge and competence to perform the technical steps with confidence. In these cases, the students were allowed to perform increasingly more subsequent surgical steps, until they were capable of successfully operating on a simple case on their own, under the guidance and assistance of the surgeon in charge. This result was not surprising.

\section{DISCUSSION}

Several points deserve deep consideration, including the question: "If it worked well, why was the Inguinal Hernia Surgery League interrupted?

The learning-by-doing model, or learning by experience, cannot be applied to the teaching of medicine and specially to the teaching of surgery $^{13}$. In order to learn things this way, students must interact with the reason for their learning and by means of living the right or wrong experiences they must abstract the fundamental principles to build up their knowledge. This learning method, understandable if the object of learning is a computer software, for instance, is not suitable when the object of learning involves human suffering. In the proposed model, the students acquire the knowledge through the close and real contact with the professor. Therefore, the knowledge is not empirically acquired by trial and error. Instead, it is verbally transmitted to the student and in a practical way by demonstrating the techniques to be learned and at the workshops, where the technical movements are learned and trained. Even if there is intellectual transmission of knowledge, the students go through practical experiences, under supervision and experimenting the failures and successes inherent to the surgical act performed by the professor. The proposed model consists of "learning by experience", but it is not based on pure empirical ${ }^{13}$ experimentation. Led by the professor, the student lives the real experience and participates in the responsibility for the success of the act. While the medical students learn basic concepts related to the surgical technique, they are also in contact with the SUS reality and learns the basic organizations of the system involved in the patient's hospitalization. For the first time during their undergraduate years, the students are required to adopt a professional attitude in the presence of a sick person and this attitude must be deeply represented by the humanistic characteristic. The patients and their suffering come first $^{14}$, and the physician's compassion for their fellow creature's pain is the driving force behind their attitudes. Here, we do not provide accessible data on this concern because the learning of humanistic skills has not been rated. Humanistic behavior has been mandatory for the students as a requirement for being part of the group. The expected humanistic attitudes have been previously discussed, so this has been required. It was remarkable to witness the humanistic progress of the students. Since this is a personal feeling, expressed by an experienced professor who followed the students all the time and considering that this is an experience report where personal feelings are suitable, we consider that this point deserves to be reported.

The teaching and learning model based on the academic leagues have problems. Overall, the leagues originate from the student's initiatives, different from the case described herein, where the initiative was taken by the professor. When this does not happen, the students throw themselves in the search for one or more people in charge of the group, who many times only have a decorative role. There are no data about this aspect in Brazil ${ }^{10}$, but as a university professor who followed the proliferation of academic leagues throughout our country, my personal impression is that in many cases the students become dependent on their own initiative, with little or no practical guidance. There are some who may argue that the group is a model of medical education, which turns the students away from the curricular actions and overloads the professor, who starts worrying about the group's activities and devoting less and less time to the regular graduation activities, research and extended education ${ }^{12}$. Moreover, the critics argue that the model leads the student to precocious specialization,

REVISTA BRASILEIRA DE EDUCAÇÃo MÉDICA

4 44 (1) : e039; 2020 
contradicting the physician's qualification based on the curricular guidelines for the medical course, which aims at the qualification of a generalist doctor, capable of interfering in society and interacting with it ${ }^{1,2}$. In addition, some argue that a medical school is not expected to form a surgeon still during graduation. In relation to this argument, it is possible to counter-argue that it is not the purpose of the league to qualify surgeons. What was intended was that, at the same time that the needs of development of surgical skills during the medical course were meet, the generalist who graduated from a medical school could have experience and competence to solve the simpler surgical cases, even if they were sent to work at the most remote inland areas. It was also intended that the graduate could at least feel assured and capable of taking care of simple cases that could be solved in the primary level care ambulatories, instead of further burdening the problematic emergency services in the big cities. It is important to bear in mind that in Brazil there are remote regions with little or no medical assistance, where there are doctors who did not have the opportunity of attending medical residency. For this reason, it is fundamental that the doctor sent to these regions have the ability to treat simpler surgical cases. The critics can only acknowledge that the emergency services receive daily a significant number of patients presenting with simple surgical problems. These patients get to this point because they were evaluated at a previous visit to the health services by a professional who was probably incapable of evaluating a surgical case. It is also necessary to acknowledge that those medical schools are deeply responsible for this result. Although it is admissible that the model may lead to an early specialization, there are two arguments which go against this idea. The first one is that those students who were members of the inguinal hernia academic surgery league had already decided for the surgery as a possibility for medical practice. It is the student who comes to the league, not the opposite. The second argument is that not all those students who participated in the league made the option for surgery or anesthesiology.

Perhaps the most significant criticism to the model described herein is that it only helps a small number of students. So that there would be an almost personal follow-up of the students' performance and achievements, without any important damage to the regular curricular load, it is necessary that the professor be concerned with a few students. Nine students per year mean just $1 \%$ of the ones yearly enrolled in the School of Medical Sciences of the University of Pernambuco. This represents a negligible number of students assisted by the model. If more professors were willing to take other groups of students, aiming at increasing the number of enrolled students, the physical and functional structure of the school-hospital would not bear the demand for hours in surgical blocks, beds and other premises. It is quite true that the number of students semi-annually enrolled in the School of Medical Sciences is much higher than the number that the faculty can handle with its current building structure. Even if this number were suitable to the faculty's size, the league would go on treating a small number of students. For these reasons, the initiative was discontinued in 2010. In addition to leaving most of the students without opportunities, this group offered heavy competition to the general surgery residents of the first year of the University Hospital. On that occasion, we had five doctors in the first year of residency, five doctors in the second year and two doctors in the third year. The total number of residents comprised twelve doctors. These doctors have contributed to the surgery as aides, and if they had any experience, it was as a surgeon under the supervision of a senior surgeon. At the end of the second year, the doctors had performed a number of surgeries that allowed them to treat most cases of inguinal hernia, but a representation of the residents wrote to me to report that some students had more experience and confidence in themselves to treat patients with inguinal hernia than the residents of the first year had.

These residents saw the few occasions when they had a surgical opportunity diminish due to the competition offered by the Hernia group. To sum it up, we offered an interesting teaching-learning model to a few students and took opportunities away from the residents. This fact made me consider the continuation of this league.

A league is an effective way to promote the learning of skills but should not compensate for the shortage of resources and regular curriculum limitations. ${ }^{15}$ Basic surgical training is of paramount relevance in undergraduate training. Both the league and the regular curriculum can help to achieve this goal. They are not exclusive, although they depend on the resources of the medical school. In the setting of Brazilian schools of medicine, this is particularly critical. Public medical schools are underfunded by the governments in charge, resulting in limited resources to meet all needs. In our case, eighteen years have gone out since the last relevant change in the curriculum. Throughout all these years the school has been able to offer to the students acceptable learning of basic surgical skills. In this setting, the League may be a solution, despite the natural criticism of the learning model. ${ }^{15}$ The challenges to be faced for carrying out strengthening health actions in SUS require commitment on the part of the higher education institutions, with the articulation of teaching proposals that contemplate inclusive and citizen assistance to their users. In addition, the health professionals must share participative, innovative and creative scenarios of health action, but mainly emancipatory ones. From the impersonal analysis of the discussion presented above, it is possible to conclude that the model discussed herein allows for a very rich pedagogical experience, offering students the opportunity of acquiring human and technical qualification, extremely interesting for the SUS objectives. However, the proposed model does not represent a solution for the flaws and omissions of the school curricular grid. It is only in a completely different curricular conception, exempted from economic and political interests that "swallow" the medical schools with students, in a model that meant an educational proposal which would allow for the personal follow-up of the students by the professors, the educational model proposed herein would be really valid.

\section{REFERENCES}

1. Brasil. Diretrizes Curriculares Nacionais do Curso de Graduação em Medicina. Diário da União 2014;1:8-11.

2. Camargo CP, Gemperli R, Otavio J, Junior CA. New paradigms in the teaching of surgery for medical students 2018;97(1):8-9.

3. Barros K, Batista C. Formação dos Profissionais de Saúde para o SUS : significado e cuidado. Saude soc 2011;20:884-899.

4. Harari Y, Darwin C. Animals in the teaching of surgical techniques during the medical graduation: a cost-benefit question. Rev Med 2018;97(4):446-447.

5. Camargo CP, Gemperli R. Learning methodology in surgical training. Rev Med 2018;97(1):7-11.

6. Canôas WS. O significado das ligas acadêmicas para estudantes

REVISTA BRASILEIRA DE EDUCAÇC̃̃ MÉDICA

5 44 (1) : e039; 2020 
de medicina. Faculdade de Ciências Médicas e da Saúde Mestrado Profissional em Educação nas Profissões de Saúde 2016.

7. Reime MH, Johnsgaard T, Kvam FI, Aarflot M, Engeberg JM, Breivik M, et al. Learning by Viewing Versus Learning by Doing: A Comparative Study of Observer and Participant Experiences During an Interprofessional Simulation Training. J Interprof Care 2017;31(1):51-59.

8. Vertrees SM, Shuman AG, Fins JJ. Learning by Doing: Effectively Incorporating Ethics Education Into Residency Training. J Gen Intern Med 2013;28(4):578-583.

9. Camargo CP, Gemperli R, Junior JO. Learning methodology in surgical training. Rev Med (São Paulo). 2018;97(1):7-11. doi: http://dx.doi. org/10.11606/issn.1679-9836.v97i1p7-11

10. Torsani MB. The important role of academic leagues (extensions) in Brazilian medical education. Rev Assoc Med Bras 2019;65(2): 98-99. http://dx.doi.org/10.1590/1806-9282.65.2.98

11. Hamamoto Filho PT, VillasBôas PJ, Corrêa FG, Muñoz GO, Zaba M, Venditti VC, et al. Regulation of student leagues: The experience at the Botucatu School of Medicine. Rev Bras Educ Méd 2010;34:1607.

12. Tadao P. Student Leagues: Motivations and Criticisms regarding a necessary reconsideration. Rev Bras Educ Med 2014;(May). doi:10.1590/S0100-55022011000400013

13. Reime MH, Johnsgaard T, Kvam FI, et al. Learning by viewing versus learning by doing: A comparative study of observer and participant experiences during an interprofessional simulation training. J Interprof Care. 2017;31(1):51-59. doi:10.1080/13561820.2016.1233390

14. Vertrees SM, Shuman AG, Fins JJ. Learning by doing: Effectively incorporating ethics education into residency training. J Gen Intern Med. 2013;28(4):578-583. doi:10.1007/s11606-012-2277-0
15. Moreira LM, Mennin RHP, Lacaz FA de C, Bellini VC, Moreira LM, Mennin RHP, et al. Ligas Acadêmicas e Formação Médica: Estudo Exploratório numa Tradicional Escola de Medicina. Revista Brasileira de Educação Médica. 2019 Mar;43(1):115-25.

\section{AUTHORS' CONTRIBUTION}

LECM: Proponent and coordinator of the league. Revisor of the text for publication.

ACGM, DLL e AKAA contributed equally to the planning of the League, the literature review, preparation of the academic project, including the ethical and bureaucratic requirements. writing of the article and final approval of the version for publication.

\section{CONFLICTS OF INTEREST}

The authors each individually and collectively declare there are no conflict of interest

\section{ADDRESS FOR CORRESPONDENCE}

Luiz Eduardo Correia Miranda, Professor Adjunto de Cirurgia Geral da Faculdade de Ciências Médicas.

Universidade de Pernambuco. Rua Dhália, 74/1802, Boa Viagem, Recife, PE - CEP: 51020-290.

Email: lecmiranda@gmail.com 